Review Article

\title{
Chronic inflammation and atherosclerosis
}

\section{: A critical role for renin angiotensin system that is activated by lifestyle-related diseases}

\author{
Masataka Sata ${ }^{1, *}$ and Daiju Fukuda ${ }^{2)}$ \\ 1) Department of Cardiovascular medicine, Institute of Health Bioscience, The University of Tokushima \\ Graduate School, Tokushima, Japan. \\ 2) Cardiovascular Division, Department of Medicine, Brigham and Women's Hospital, Harvard Medical \\ School, Boston, USA.
}

It is generally believed that atherosclerosis is a chronic inflammatory disease that is promoted by lifestyle-related diseases, such as hypertension, dyslipidemia, and diabetes. The renin-angiotensin system (RAS) has been demonstrated to play a critical role in the initiation and progression of atherosclerosis, thereby contributing to development of cardiovascular diseases. Angiotensin II (Ang II), a major substrate in RAS, stimulates atherosclerosis through various deleterious effects such as endothelial dysfunction, cellular proliferation and inflammation. Reactive oxygen species (ROS) play a major role in the athero-promoting actions of Ang II. In fact, recent basic and clinical studies demonstrated that pharmacological inhibition of renin-angiotensin system is effective in prevention of atherosclerotic diseases. Elucidation of molecular mechanism of chronic inflammation should lead to development of effective strategies against lifestyle-related diseases.

Rec./Acc.4/27/2011

${ }^{*}$ Correspondence should be addressed to:

Masataka Sata, MD, PhD. Department of Cardiovascular Medicine, Institute of Health Biosciences, The University of Tokushima Graduate School. 3-18-15 Kuramoto-cho, Tokushima 770-8503, Japan. Phone:+ 81-88-633-7850, Fax:+81-88-633-7894, E-mail:sata@clin.med.tokushima-u.ac.jp

Key words:

atherosclerosis, renin-angiotensin system, reactive oxygen species, inflammation 


\section{Renin-angiotensin system}

The renin-angiotensin system (RAS) has been considered as a circulating hormonal system that regulates blood pressure, blood flow, fluid volume and electrolyte balance ${ }^{1)}$. Angiotensinogen produced in the liver is cleaved to angiotensin (Ang) I in circulation by renin that is secreted from the kidney. Ang I is cleaved to Ang II by angiotensin converting enzyme (ACE) that is mainly distributed in pulmonary circulation. Ang II plays a main role in the RAS by interacting with its specific receptor, Ang II type 1 receptor (AT1R). Ang II-AT1R interaction causes vasoconstriction and aldosterone release from the adrenal gland. This classical view of the RAS has been expanded by recent findings that RAS is activated locally, particularly in the heart ${ }^{2}$, the vessel wall $^{3)}$, the kidney ${ }^{4)}$ and the brain ${ }^{5)}$. There are RAS components in these tissues, allowing local synthesis of Ang peptides. Recent reports also identified other receptors ${ }^{6)}$ and angiotensin-related peptides such as Ang $(1-7)^{7}$. Ang II was also reported to be generated by other enzymes such as chymase ${ }^{8)}$. These findings indicate that RAS could be activated locally and regulated by the complicated crosstalk of the RAS components in each organ.

\section{Local effects of an activated RAS in vasculature}

The RAS serves as a key player in the pathogenesis of atherosclerosis by simulating a series of coordinated cellular and molecular events observed in the lesions ${ }^{9}$. It is now well established that Ang II has significant pro-inflammatory actions on the vessel wall, leading to progression of atherosclerosis ${ }^{10)}$. There are two different types of Ang II receptors, AT1R and AT2R, in mammals. Both AT1R and AT2R have been identified in the vessel wall, although AT1R is believed to mediate most of the atherogenic actions of Ang $\mathrm{II}^{11)}$. The greatest AT1R density has been found on vascular smooth muscle cells and endothelial cells. In the vascular wall, ACE is readily detectable on endothelial cells and smooth muscle cells ${ }^{12}$. Most of the components of RAS could be detected in vasculature ${ }^{13)}$. RAS is activated locally in the atherosclerotic lesions ${ }^{14)}$ and in the damaged vessels ${ }^{15)}$. Thus, these results suggest that not only systemic but also local Ang II-AT1R pathway could contribute to initiation and progression of atherosclerosis.

\section{Effects of RAS on vascular cells}

Ang II up-regulates expression of adhesion molecules $^{16)}$, chemokines ${ }^{17)}$ and cytokines ${ }^{18)}$. These molecules induce endothelial cell dysfunction ${ }^{19)}$, oxidation and uptake of $\mathrm{LDL}^{20)}$, and proliferation of smooth muscle cells ${ }^{21)}$. In advanced atherosclerotic lesions, Ang II stimulates expression of matrix metalloproteinases (MMPs) ${ }^{22)}$ and plasminogen activator inhibitor- $1^{23)}$, leading to destabilization of atherosclerotic plaque and alteration of fibrinolytic balance. Ang II also up-regulates expression of VEGF that promotes adventitial angiogenesis ${ }^{24)}$ (Fig. 1).

Conversely, previous reports demonstrated that inhibition of the Ang II-AT1R pathway reduces atherosclerosis $^{25,26)}$. It is generally assumed that the beneficial effects obtained by Ang II-AT1R blocking are mediated by reduction of oxidative stress, inhibition of inflammation and improvement of endothelial cell function ${ }^{27}$. We generated apolipoprotein $\mathrm{E}$ (ApoE)-/-AT1aR-/- double knockout mice by cross-breeding ApoE-/-AT1aR+/+ mice and ApoE+/+AT1aR-/- mice ${ }^{28)}$. Moreover, genetic disruption of AT1R resulted in reduced lipid deposition and increased collagen contents in the atheroma. These results demonstrated that blockade of Ang II-AT1R pathway not only reduces atherosclerotic lesions but also stabilizes the plaque ${ }^{28)}$.

It should be noted that the production of Ang II could be increased and may act on the AT2R, when AT1R is genetically disrupted or pharmacologically blocked ${ }^{29)}$. Previous reports suggested an anti-atherogenic effect of AT2R, although its function and distribution are still under debate ${ }^{30)}$. AT2R stimulation interacts with AT1R stimulation at intracellular signaling molecules, such as through activation of phosphatase ${ }^{31)}$. In fact, Iwai et al. demonstrated that AT2R stimulation attenuates atherosclerosis through inhibition of oxidative stress and that the anti-atherosclerotic effect of an ARB could be at least partly due to AT2R stimulation by analyzing AT2R/ApoE-double-knockout mice ${ }^{32)}$.

\section{Pharmacological inhibition of renin-angiotensin system}

AT1R blockers (ARBs) specifically block Ang II binding to AT1R. Eventually, Ang II is directed to stimulate AT2R. On the other hand, ACE inhibitors (ACEIs) suppress angiotensin II production. ACEIs also inhibit break down of bradykinin, leading to 
increase in nitric oxide production. It has been reported that ARBs or ACEIs exert various favorable effects on endothelial function ${ }^{25,26,33)}$, cardiac function $^{34)}$, cerebral vascular function ${ }^{35)}$ and renal function $^{36)}$ other than blood pressure lowering. These findings suggest that blockade of RAS is an effective strategy for organ protection ${ }^{25,26,33)}$. In fact, many clinical studies demonstrated that AT1R blockers (ARBs) or ACE inhibitors are effective for patients with cardiovascular, cerebrovascular and renal diseases $^{37)}$.

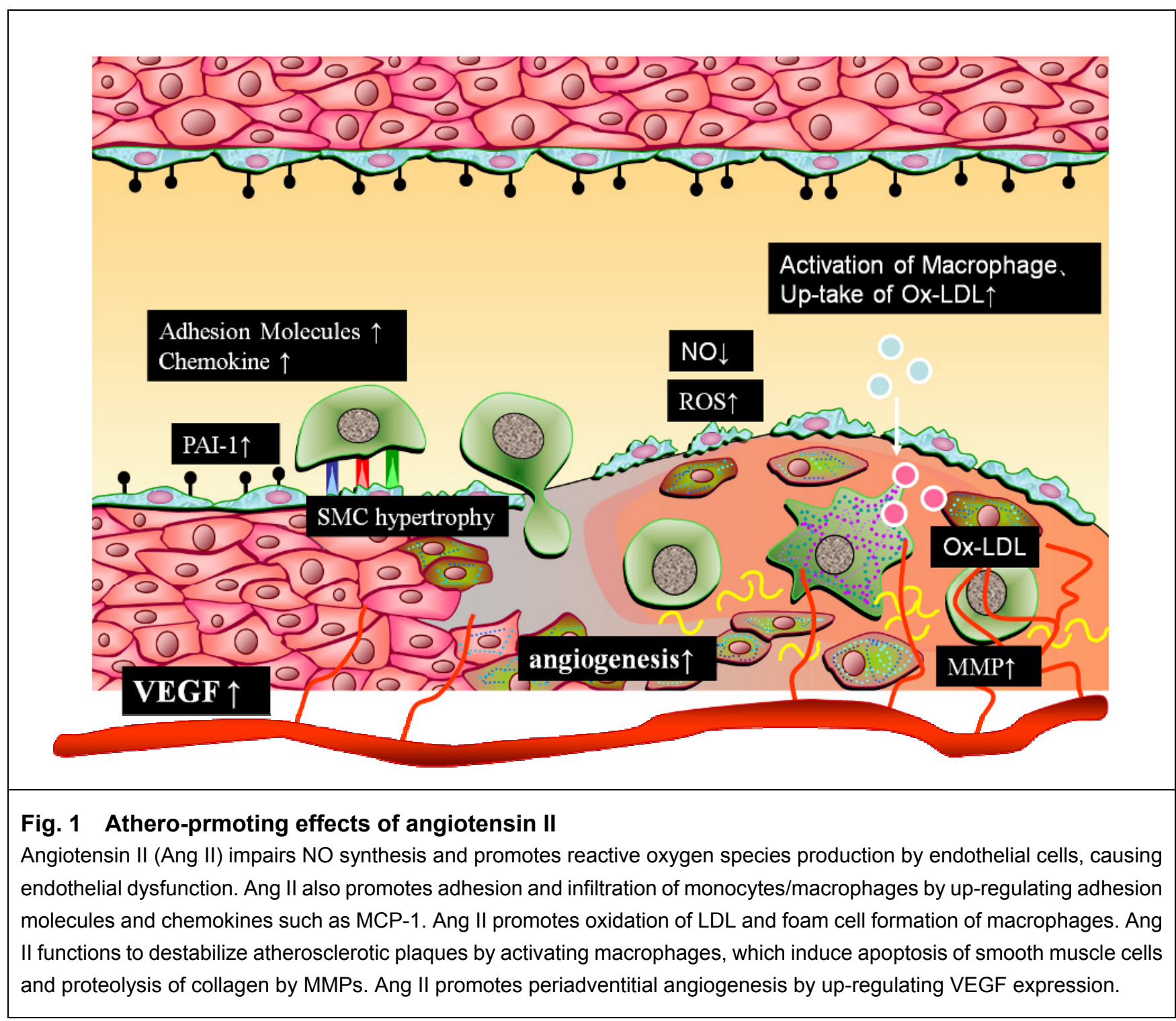

\section{Atherosclerosis is an inflammatory disease}

Atherosclerosis occurs in whole arteries and results in various organ damages, including myocardial infarction, cerebral infarction, and peripheral arterial diseases, the main cause of death in Western countries $^{38)}$. Atherosclerosis is considered to be one of the chronic inflammatory diseases ${ }^{10)}$. Although multifactorial in etiology, continuous recruitment of circulating leukocytes into the vessel wall plays crucial roles in the pathogenesis of atherosclerosis. In- flammatory cells detected in atherosclerotic lesions are derived from bone marrow (Fig. 2). Recent advances in immunology have identified several molecular pathways that induce and promote inflammatory responses in atherosclerotic lesions.

\section{Roles of reactive oxygen species in atherogenesis}

Accumulating evidence indicates that vascular reactive oxygen species (ROS) play a crucial role in atherogenesis. Among many ROS generators, nicotinamide dinucleotide phosphate $(\mathrm{NAD}(\mathrm{P}) \mathrm{H})$ oxi- 
dase-dependent pathway is important in vascular system $^{39)}$. Barry-Lane et al. demonstrated that $\mathrm{NAD}(\mathrm{P}) \mathrm{H}$ oxidase is important in the pathogenesis of atherosclerosis by analyzing the genetically modified mice that are deficient for both ApoE and p47phox, one subunits of NAD(P)H oxidase ${ }^{40)}$. In this study, the double knockout mice showed significant reduction in atherosclerotic lesion compared with that of ApoE-deficient mice. ROS acts not only as a modulator of vascular tonus but also as a second messenger to alter the vascular cell phenotypes. ROS activates mitogen-activated protein kinase ${ }^{41)}, \mathrm{Akt}^{42)}$, and JAK (janus kinase)/STAT (signal transducers and activators of transcription) ${ }^{43)}$ pathways. These signals play a crucial role in cell proliferation, apoptosis and phenotypic modification that are observed in atherosclerotic lesions.

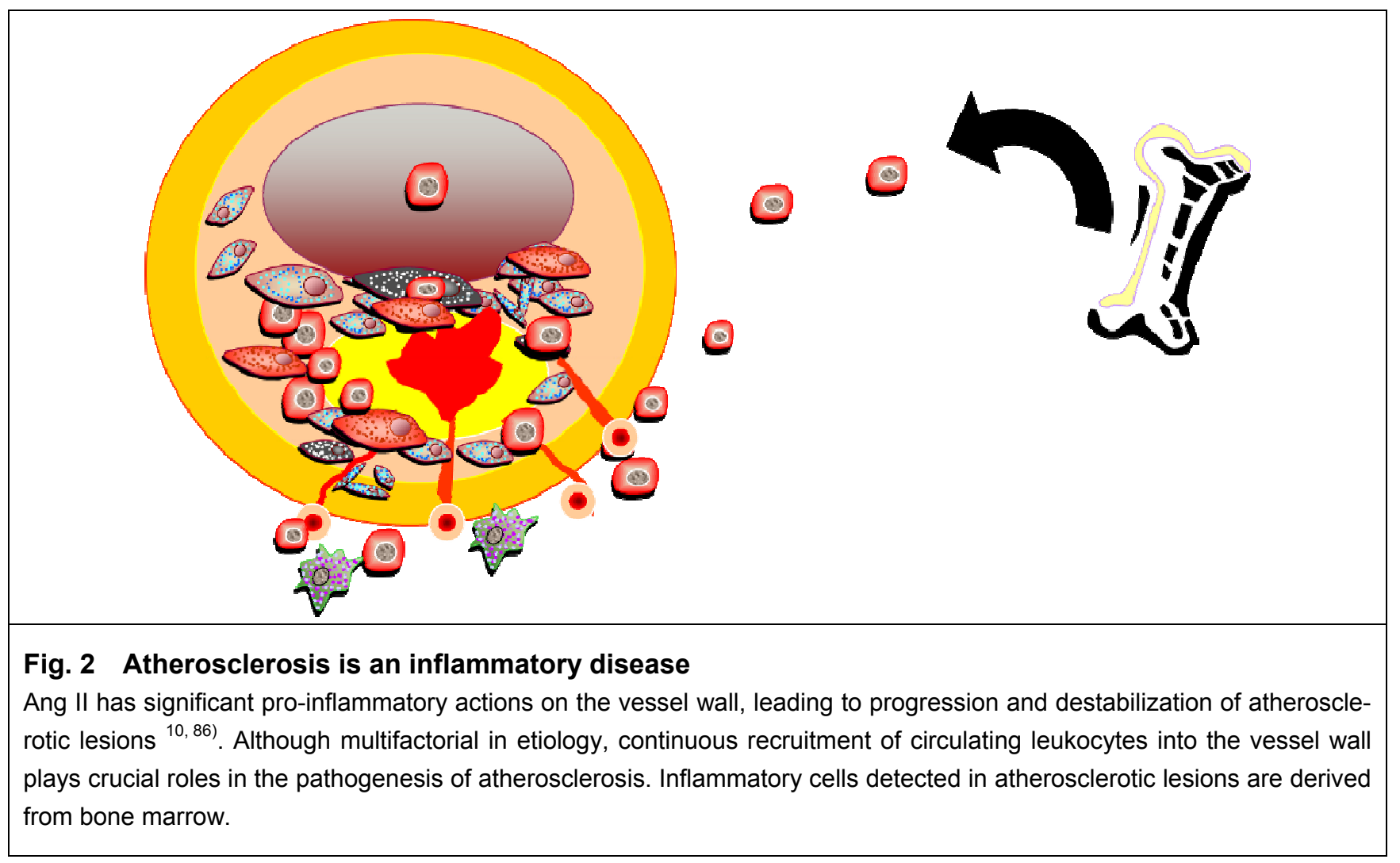

Association between RAS and ROS has been investigated extensively ${ }^{3)}$. Ang II induces production of ROS, one of the most important mediators of the atherogenic actions of $\mathrm{RAS}^{44)}$. Although Ang II up-regulates expression of cytokines such as interleukin- 6 and tumor necrosis factor- $\alpha$, pharmacological blockade of AT1R with ARBs would not so effective to inhibit cytokine production completely. It was demonstrated that cytokines such as TNF- $\alpha$, IL-1 $\beta$ and IFN- $\gamma$ increase mitochondrial- and NADPH oxidase-generated ROS ${ }^{45}$. Thus, the in vivo inhibition of intracellular ROS production by blocking vascular AT1R may play an adjunct rather than a major role to prevent or reduce atherogenesis. The above suggestion could be also compatible with the accumulating findings that AT1R blocker could only have a modest effect on atherosclerosis diseases in patients ${ }^{46)}$.

\section{Roles of inflammatory cells in atherogenesis}

In initiation and progression of atherosclerotic lesions, RAS is activated locally and stimulates expression of vascular cellular adhesion molecule-1, intracellular adhesion molecule-1 and monocyte chemotactic protein-1 (MCP-1) ${ }^{16)}$. These molecules accelerate recruitment of inflammatory cells into the vessel walls. It is generally believed that the vascular endothelium serves as an inflammatory barrier by providing a nonadherent surface to leukocytes. However, upon Ang II stimulation, endothelium turns to promote infiltration of inflammatory cells by expressing adhesion molecules and chemokines. After migrating into the vessel wall, monocytes transform into macrophages and contribute to lipid deposition in the plaque ${ }^{47}$. Monocytes/macrophages se- 
cret chemokines ${ }^{48)}$ and $\mathrm{MMPs}^{49)}$, leading to acceleration of atherosclerotic lesion development. Moreover, recruited leukocytes themselves have $\mathrm{NAD}(\mathrm{P}) \mathrm{H}$ oxidase subunits and serve as a source of $\operatorname{ROS}^{50)}$. Thus, activated RAS promotes interaction between circulating leukocytes and vascular cells, an important step in the pathogenesis of atherosclerosis ${ }^{9}$. High levels of ACE expression and Ang II have been shown in experimental and human atherosclerotic lesions $^{51)}$. In human atherosclerotic lesions, ACE, Ang II, and its receptor are co-localized at the areas of inflammation ${ }^{3)}$. Taken together, these results suggest that local effects of an activated RAS in vessel walls promote infiltration of inflammatory cells into the vessel walls, a key feature of atherosclerosis.

\section{Local effects of an activated RAS in bone marrow}

Bone marrow is a highly organized organ. All blood cells derive from hematopoietic stem cells through complex steps of division and maturation. Previous reports elucidated the surface receptors, cytokines, and growth factors that potentially regulate hematopoiesis ${ }^{52)}$. However, the precise mechanism by which the proliferation and differentiation of hematopoietic stem cells are regulated is not fully understood.

A locally activated RAS has been suggested to contribute to differentiation and proliferation of bone marrow-derived cells ${ }^{53)}$. Recently, we proposed a hypothesis that the local RAS in bone marrow plays crucial roles in atherosclerosis ${ }^{25,28)}$. We demonstrated that Ang II-AT1R pathway in bone marrow contributes to atherosclerotic development in the hypercholesterolemic mice.

Randomized clinical trials have proved beneficial effects of ACE inhibitors or ARBs in the treatment of cardiovascular diseases ${ }^{54}$. However, it was reported that ACE inhibitors or ARBs may have suppressive effects on hematological processes. It is reported that ACE inhibitors induced anemia and leukocytopenia ${ }^{55)}$. ACE inhibitors and ARBs have been shown to effectively reduce hematocrit values in patient with renal transplantation ${ }^{56)}$. Haznedaroglu et al. proposed the existence of a locally activated RAS in bone marrow that contributes to hematological processes $^{57)}$. Others also demonstrated the presence of RAS components in bone marrow and circulating blood cells. Rodgers et al. showed the presence of AT1R in $\mathrm{CD} 34^{+} \mathrm{CD} 38^{+}$cells, $\mathrm{CD} 34^{+} \mathrm{CD} 38^{-}$cells and lymphocytes $^{58)}$. The authors demonstrated that Ang
II accelerated colony formation of hematopoietic progenitor cells from murine lineage negative bone marrow cells in a dose dependent manner. Ang II also stimulated differentiation of human CD34+ hematopoietic progenitors from cord blood. The effects of Ang II on hematopoietic progenitors were clearly inhibited by an ARB, losartan. It was also reported that Ang II and Ang (1-7) accelerated recovery of circulating leukocytes and the myeloid lineage cells in bone marrow after chemotherapy and irradiation $^{59,60)}$. Similarly, other reports demonstrated that RAS components in bone marrow contribute to hematopoiesis ${ }^{61)}$. On the other hand, several papers reported that a local RAS in bone marrow plays a role in the pathological hematopoiesis ${ }^{62)}$. Bone marrow stromal cells also express AT1R, whose activation possibly causes secretion of growth factors or cytokines that increase hematopoietic progenitor cells ${ }^{63)}$. Thus, it is likely that angiotensin peptides are potential stimulators of proliferation and differentiation of multiple hematopoietic lineages under physiological and pathological conditions.

\section{Ang II stimulates contribution of bone marrow-derived cells to the pathogenesis of atherosclerosis}

Recently, we proposed that bone marrow-derived cells significantly contribute to pathogenesis of atherosclerosis $^{25,28,64-71)}$. This phenomenon was confirmed not only in animal models of vascular diseases, but also in human samples ${ }^{72,73)}$. Ang II is supposed to promote contribution of bone marrow-derived cells to atherosclerosis by enhancing their mobilization, recruitment, differentiation, and proliferation $^{25,28)}$. To confirm this notion, we performed bone marrow transplantation from GFP (Green Fluorescent Proteins)+/+ApoE-/- mice to GFP-/-ApoE-/- mice. Administration of Ang II to these bone marrow chimeric mice promoted atherosclerosis lesion formation, which was associated with increased infiltration of bone marrow-derived GFP-positive cells to the lesion ${ }^{25,28)}$ (Fig. 3A). We also observed that Ang II infusion increased the number of smooth muscle progenitor cells, which are peripheral blood cells that turn to $\alpha$-smooth muscle actin-positive cells after culture in the presence of PDGF-BB $^{70)}$ (Fig. 3B). These smooth muscle-like cells expressed abundant matrix metalloproteinase-9 (MMP-9), which substantially contribute to destabilization of atherosclerotic plaques. 
A

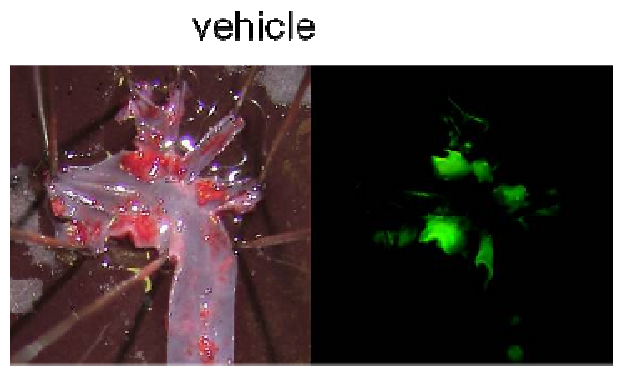

B

Human peripheral blood-derived smooth muscle-like cells

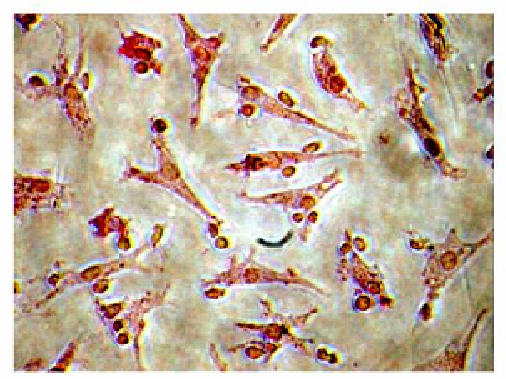

a-SMA
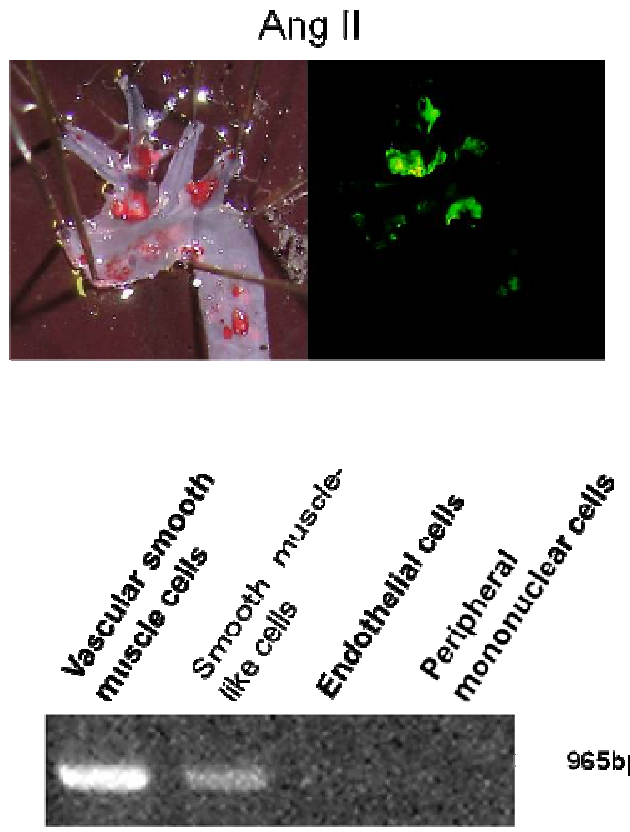

$965 \mathrm{bp}$

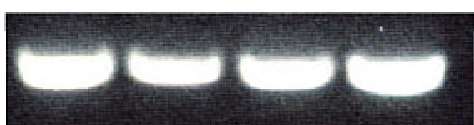

452bp

GAPDH

MMP-9

$70 \mathrm{bp}$

\section{Fig. 3 Ang II promotes accumulation of macrophages in atherosclerotic plaque}

A) Ang II infusion into the bone marrow-chimeric mice promoted atherosclerotic lesion formation as determined by en face Sudan IV staining. Bone marrow-derived GFP-positive cells accumulated the sites of atherosclerosis.

B) $\alpha$-smooth muscle actin-positive cells could be obtained from the culture of human peripheral mononuclear cells. Those smooth muscle-like cells expressed MMP-9.

\section{RAS and endothelial progenitor cells}

It is a generally accepted view that atherosclerotic lesions are initiated by endothelial cell damage, followed by monocyte/macrophage adhesion and invasion as well as smooth muscle cell migration and proliferation ${ }^{74,75)}$. Although there are a number of cellular and molecular differences, restenosis after angioplasty shares an important pathophysiological process with atherosclerosis, where injuries to the endothelium are followed by impaired re-endothelialization $^{76,77)}$. It has been believed that re-endothelialization is caused only by migration and proliferation of adjacent endothelial cells in the vessel wall ${ }^{78)}$. However, accumulating evidence indicates that bone marrow derived endothelial progenitor cells (EPCs) also participate in this process ${ }^{79)}$. EPC-dependent neovascularization has been implicated in collateral development in occlusive vascular diseases ${ }^{80}$. Bone marrow cells including stem cells express AT1R. Thus, it is possible that a local RAS in bone marrow has a role in EPC biology leading to neovascularization. Actually, it was demonstrated that activation of RAS stimulates EPC proliferation and neovascularization $^{81)}$. These studies suggest that ROS may be involved in the balance between self-renewal and differentiation of progenitors and that anti-oxidant may play a role in preservation of stemness of progenitors $^{82)}$. Murohara and his colleagues showed that the Ang II-AT1R pathway plays an important role in ischemia-induced angiogenesis by supporting inflammatory cell infiltration and angiogenic cytokine expression ${ }^{83}$. On the other hand, it was reported that blockade of RAS increase the number of EPC and neovascularization in animals models of metabolic diseases $^{84)}$. These studies suggested that Ang II accelerates the onset of EPC senescence by a gp91phox-mediated increase of oxidative stress 
leading to impairment of EPC proliferation. Under pathological conditions, RAS may be over-activated and the excess production of Ang II might accelerate EPC senescence, resulting in the impairment of EPC function. Future study is required to confirm that RAS is essential for EPC proliferation and neovascularization but excessive activation of RAS may turn to enhance senescence and dysfunction of $\mathrm{EPCs}^{71)}$.

\section{Closing remarks}

Our findings demonstrate that RAS not only in vessel wall but also in bone marrow-derived cells plays a role in the pathogenesis of atherosclerosis, at least in part, by accelerating infiltration of bone marrow-derived inflammatory cells in the vessel wall $^{28,67,85)}$. Therefore, blockade of AT1 receptor not only in vascular cells but also in bone marrow could be an important strategy to prevent progression and destabilization of atherosclerotic plaques. Elucidation of molecular mechanism of chronic inflammation should lead to development of effective strategies against lifestyle-related diseases.

\section{Acknowledgement}

This study was supported in part by grants from the Ministry of Education, Culture, Sports, Science and Technology and the Ministry of Health, Labor and Welfare of Japan.

\section{References}

1) Oparil S, Haber E: The renin-angiotensin system (first of two parts). N Engl J Med. 1974; 291: 389-401.

2) Cohn JN, Tognoni G: A randomized trial of the angiotensin-receptor blocker valsartan in chronic heart failure. N Engl J Med. 2001; 345: 1667-1675.

3) Dzau VJ. Theodore cooper lecture: Tissue angiotensin and pathobiology of vascular disease: A unifying hypothesis. Hypertension. 2001; 37: 1047-1052.

4) Cheng HF, Becker BN, Burns KD, Harris RC: Angiotensin II upregulates type-1 angiotensin II receptors in renal proximal tubule. J Clin Invest. 1995; 95: 2012-2019.

5) Morimoto $\mathrm{S}$, Cassell MD, Sigmund $\mathrm{CD}$ : The brain renin-angiotensin system in transgenic mice carrying a highly regulated human renin transgene. Circ Res. 2002; 90: 80-86.
6) Stoll M, Steckelings UM, Paul M, Bottari SP, Metzger R, Unger T: The angiotensin AT2-receptor mediates inhibition of cell proliferation in coronary endothelial cells. J Clin Invest. 1995; 95: 651-657.

7) Ferrario CM, Brosnihan KB, Diz DI, Jaiswal N, Khosla MC, Milsted A, Tallant EA: Angiotensin-(1-7): A new hormone of the angiotensin system. Hypertension. 1991; 18: III126-III133.

8) Arakawa K, Urata H: Hypothesis regarding the pathophysiological role of alternative pathways of angiotensin II formation in atherosclerosis. Hypertension. 2000; 36: 638-641.

9) Petnehazy T, Stokes KY, Wood KC, Russell J, Granger DN: Role of blood cell-associated AT1 receptors in the microvascular responses to hypercholesterolemia. Arterioscler Thromb Vasc Biol. 2006; 26: 313-318.

10) Brasier AR, Recinos A, 3rd, Eledrisi MS: Vascular inflammation and the renin-angiotensin system. Arterioscler Thromb Vasc Biol. 2002; 22: 1257-1266.

11) Sayeski PP, Bernstein KE: Signal transduction mechanisms of the angiotensin II type AT(1)-receptor: Looking beyond the heterotrimeric g protein paradigm. J Renin Angiotensin Aldosterone Syst. 2001; 2: 4-10.

12) Fernandez-Alfonso MS, Martorana PA, Licka I, van Even P, Trobisch D, Scholkens BA, Paul M: Early induction of angiotensin i-converting enzyme in rat carotid artery after balloon injury. Hypertension. 1997; 30: 272-277.

13) Hellmann W, Suzuki F, Ohkubo H, Nakanishi S, Ludwig G, Ganten D: Angiotensinogen gene expression in extrahepatic rat tissues: Application of a solution hybridization assay. Naunyn Schmiedebergs Arch Pharmacol. 1988; 338: 327-331.

14) Daugherty A, Rateri DL, Lu H, Inagami $T$, Cassis LA: Hypercholesterolemia stimulates angiotensin peptide synthesis and contributes to atherosclerosis through the AT1a receptor. Circulation. 2004; 110: 3849-3857.

15) Iwai $N$, Izumi $M$, Inagami $T$, Kinoshita $M$ : Induction of renin in medial smooth muscle cells by balloon injury. Hypertension. 1997; 29: 1044-1050.

16) Pueyo ME, Gonzalez W, Nicoletti A, Savoie F, Arnal JF, Michel JB: Angiotensin II stimulates endothelial vascular cell adhesion molecule-1 via nuclear 
factor-kappab activation induced by intracellular oxidative stress. Arterioscler Thromb Vasc Biol. 2000; 20: 645-651.

17) Gu L, Okada Y, Clinton SK, Gerard C, Sukhova GK, Libby P, Rollins BJ: Absence of monocyte chemoattractant protein-1 reduces atherosclerosis in low density lipoprotein receptor-deficient mice. Mol Cell. 1998; 2: 275-281.

18) Brasier AR, Jamaluddin M, Han $Y$, Patterson $C$, Runge MS: Angiotensin II induces gene transcription through cell-type-dependent effects on the nuclear factor-kappab (NF-kappab) transcription factor. Mol Cell Biochem. 2000; 212: 155-169.

19) Harrison DG: Cellular and molecular mechanisms of endothelial cell dysfunction. J Clin Invest. 1997; 100: 2153-2157.

20) Daugherty A, Manning MW, Cassis LA: Angiotensin II promotes atherosclerotic lesions and aneurysms in apolipoprotein E-deficient mice. J Clin Invest. 2000; 105: 1605-1612.

21) Griendling KK, Ushio-Fukai M, Lassegue B, Alexander RW: Angiotensin II signaling in vascular smooth muscle. New concepts. Hypertension. 1997; 29: 366-373.

22) Luchtefeld M, Grote K, Grothusen C, Bley S, Bandlow N, Selle T, Struber M, Haverich A, Bavendiek U, Drexler H, Schieffer B: Angiotensin II induces MMP-2 in a p47phox-dependent manner. Biochem Biophys Res Commun. 2005; 328: 183-188.

23) Vaughan DE, Lazos SA, Tong K: Angiotensin II regulates the expression of plasminogen activator inhibitor-1 in cultured endothelial cells. A potential link between the renin-angiotensin system and thrombosis. J Clin Invest. 1995; 95: 995-1001.

24) Moreno PR, Purushothaman KR, Sirol M, Levy AP, Fuster V: Neovascularization in human atherosclerosis. Circulation. 2006; 113: 2245-2252.

25) Fukuda D, Sata M: Role of bone marrow renin-angiotensin system in the pathogenesis of atherosclerosis. Pharmacol Ther. 2008;118: 268-276.

26) Fukuda D, Enomoto S, Nagai R, Sata M: Inhibition of renin-angiotensin system attenuates periadventitial inflammation and reduces atherosclerotic lesion formation. Biomed Pharmacother. 2009; 63: 754-761.

27) Li Z, Iwai M, Wu L, Liu HW, Chen R, Jinno T, Su- zuki J, Tsuda M, Gao XY, Okumura M, Cui TX, Horiuchi M: Fluvastatin enhances the inhibitory effects of a selective AT1 receptor blocker, valsartan, on atherosclerosis. Hypertension. 2004; 44: 758-763.

28) Fukuda D, Sata M, Ishizaka N, Nagai R: Critical role of bone marrow angiotensin II type 1 receptor in the pathogenesis of atherosclerosis in apolipoprotein e deficient mice. Arterioscler Thromb Vasc Biol. 2008; 28: 90-96.

29) Grossman E, Peleg E, Carroll J, Shamiss A, Rosenthal $\mathrm{T}$ : Hemodynamic and humoral effects of the angiotensin II antagonist losartan in essential hypertension. Am J Hypertens. 1994; 7: 1041-1044.

30) Batenburg WW, Tom B, Schuijt MP, Danser AH: Angiotensin II type 2 receptor-mediated vasodilation. Focus on bradykinin, no and endothelium-derived hyperpolarizing factor(s). Vascul Pharmacol. 2005; 42: 109-118.

31) Nakagami H, Cui TX, Iwai M, Shiuchi T, Takeda-Matsubara Y, Wu L, Horiuchi M: Tumor necrosis factor-alpha inhibits growth factor-mediated cell proliferation through SHP-1 activation in endothelial cells. Arterioscler Thromb Vasc Biol. 2002; 22: 238-242.

32) Iwai M, Chen R, Li Z, Shiuchi T, Suzuki J, Ide A, Tsuda M, Okumura M, Min LJ, Mogi M, Horiuchi M: Deletion of angiotensin II type 2 receptor exaggerated atherosclerosis in apolipoprotein E-null mice. Circulation. 2005; 112: 1636-1643.

33) Fukuda D, Enomoto S, Hirata Y, Nagai R, Sata M: The angiotensin receptor blocker, telmisartan, reduces and stabilizes atherosclerosis in apoE and AT1aR double deficient mice. Biomed Pharmacother. 2010; 64: 712-717.

34) Pfeffer MA, McMurray JJ, Velazquez EJ, Rouleau JL, Kober L, Maggioni AP, Solomon SD, Swedberg K, Van de Werf F, White H, Leimberger JD, Henis M, Edwards S, Zelenkofske S, Sellers MA, Califf RM: Valsartan, captopril, or both in myocardial infarction complicated by heart failure, left ventricular dysfunction, or both. N Engl J Med. 2003; 349: 1893-1906.

35) Chapman N, Huxley R, Anderson C, Bousser MG, Chalmers J, Colman S, Davis S, Donnan G, MacMahon S, Neal B, Warlow C, Woodward M: Effects of a perindopril-based blood pressure-lowering re- 
gimen on the risk of recurrent stroke according to stroke subtype and medical history: The progress trial. Stroke. 2004; 35: 116-121.

36) Barnett AH, Bain SC, Bouter P, Karlberg B, Madsbad S, Jervell J, Mustonen J: Angiotensin-receptor blockade versus converting-enzyme inhibition in type 2 diabetes and nephropathy. $\mathrm{N}$ Engl $\mathrm{J}$ Med. 2004; 351: 1952-1961.

37) Schrader J, Luders S, Kulschewski A, Hammersen F, Plate K, Berger J, Zidek W, Dominiak P, Diener HC: Morbidity and mortality after stroke, eprosartan compared with nitrendipine for secondary prevention: Principal results of a prospective randomized controlled study (moses). Stroke. 2005; 36: 1218-1226.

38) Lusis AJ: Atherosclerosis. Nature. 2000; 407: 233-241.

39) Griendling KK, Sorescu D, Ushio-Fukai M: $\mathrm{Nad}(\mathrm{p}) \mathrm{h}$ oxidase: Role in cardiovascular biology and disease. Circ Res. 2000; 86: 494-501.

40) Barry-Lane PA, Patterson C, van der Merwe M, Hu Z, Holland SM, Yeh ET, Runge MS: P47phox is required for atherosclerotic lesion progression in apoe(-/-) mice. J Clin Invest. 2001; 108: 1513-1522.

41) Viedt C, Soto U, Krieger-Brauer HI, Fei J, Elsing C, Kubler W, Kreuzer J: Differential activation of mitogen-activated protein kinases in smooth muscle cells by angiotensin II: Involvement of p22phox and reactive oxygen species. Arterioscler Thromb Vasc Biol. 2000; 20: 940-948.

42) Ushio-Fukai M, Alexander RW, Akers M, Yin Q, Fujio Y, Walsh K, Griendling KK: Reactive oxygen species mediate the activation of akt/protein kinase b by angiotensin II in vascular smooth muscle cells. J Biol Chem. 1999; 274: 22699-22704.

43) Schieffer B, Luchtefeld M, Braun S, Hilfiker A, Hilfiker-Kleiner D, Drexler H: Role of nad(p)h oxidase in angiotensin II-induced jak/stat signaling and cytokine induction. Circ Res. 2000; 87: 1195-1201.

44) Warnholtz A, Nickenig G, Schulz E, Macharzina R, Brasen JH, Skatchkov M, Heitzer T, Stasch JP, Griendling KK, Harrison DG, Bohm M, Meinertz T, Munzel T: Increased nadh-oxidase-mediated superoxide production in the early stages of atherosclerosis: Evidence for involvement of the renin-angiotensin system. Circulation. 1999; 99: 2027-2033.
45) Yang D, Elner SG, Bian ZM, Till GO, Petty HR, Elner VM: Pro-inflammatory cytokines increase reactive oxygen species through mitochondria and nadph oxidase in cultured rpe cells. Exp Eye Res. 2007; 85: 462-472.

46) Verma S, Strauss M: Angiotensin receptor blockers and myocardial infarction. Bmj. 2004; 329: 1248-1249.

47) Keidar S, Heinrich R, Kaplan M, Hayek T, Aviram $\mathrm{M}$ : Angiotensin II administration to atherosclerotic mice increases macrophage uptake of oxidized ldl: A possible role for interleukin-6. Arterioscler Thromb Vasc Biol. 2001; 21: 1464-1469.

48) Schmeisser A, Soehnlein O, Illmer T, Lorenz HM, Eskafi S, Roerick O, Gabler C, Strasser R, Daniel WG, Garlichs CD: Ace inhibition lowers angiotensin II-induced chemokine expression by reduction of nf-kappab activity and AT1 receptor expression. Biochem Biophys Res Commun. 2004; 325: 532-540.

49) Galis ZS, Khatri JJ: Matrix metalloproteinases in vascular remodeling and atherogenesis: The good, the bad, and the ugly. Circ Res. 2002; 90: 251-262.

50) Cathcart MK: Regulation of superoxide anion production by nadph oxidase in monocytes/macrophages: Contributions to atherosclerosis. Arterioscler Thromb Vasc Biol. 2004; 24: 23-28.

51) Hoshida S, Kato J, Nishino M, Egami $Y$, Takeda $T$, Kawabata M, Tanouchi J, Yamada Y, Kamada T: Increased angiotensin-converting enzyme activity in coronary artery specimens from patients with acute coronary syndrome. Circulation. 2001; 103: 630633.

52) Heissig B, Ohki Y, Sato Y, Rafii S, Werb Z, Hattori $\mathrm{K}$ : A role for niches in hematopoietic cell development. Hematology. 2005; 10: 247-253.

53) Rodgers KE, DeCherney AH, St Amand KM, Dougherty WR, Felix JC, Girgis WW, diZerega GS: Histologic alterations in dermal repair after thermal injury effects of topical angiotensin II. J Burn Care Rehabil. 1997; 18: 381-388.

54) Schrader J, Luders S, Kulschewski A, Berger J, Zidek W, Treib J, Einhaupl K, Diener HC, Dominiak P: The access study: Evaluation of acute candesar$\tan$ cilexetil therapy in stroke survivors. Stroke. 2003; 34: 1699-1703. 
55) Vasku A, Soucek M, Znojil V, Rihacek I, Cidl K, Strelcova L, Vacha J: Does angiotensin I-converting enzyme inhibitor therapy have an antiproliferative effect on blood-forming bone marrow? Exp Hematol. $1998 ; 26: 277-279$.

56) Conlon PJ, Smith SR, Butterly DW, Brennan DC: Losartan in post-transplant erythrocytosis. Nephrol Dial Transplant. 1996; 11: 2524-2525.

57) Haznedaroglu IC, Tuncer S, Gursoy M: A local renin-angiotensin system in the bone marrow. Med Hypotheses. 1996; 46: 507-510.

58) Rodgers KE, Xiong S, Steer R, diZerega GS: Effect of angiotensin II on hematopoietic progenitor cell proliferation. Stem Cells. 2000; 18: 287-294.

59) Rodgers K, Xiong S, DiZerega GS: Effect of angiotensin II and angiotensin(1-7) on hematopoietic recovery after intravenous chemotherapy. Cancer Chemother Pharmacol. 2003; 51: 97-106.

60) Rodgers KE, Xiong S, diZerega GS: Accelerated recovery from irradiation injury by angiotensin peptides. Cancer Chemother Pharmacol. 2002; 49: 403-411.

61) Chisi JE, Wdzieczak-Bakala J, Riches AC: Inhibitory action of the peptide acsdkp on the proliferative state of hematopoietic stem cells in the presence of captopril but not lisinopril. Stem Cells. 1997; 15: 455-460.

62) Abali H, Haznedaroglu IC, Goker H, Celik I, Ozatli D, Koray Z, Caglar M: Circulating and local bone marrow renin-angiotensin system in leukemic hematopoiesis: Preliminary evidences. Hematology. 2002; 7: 75-82.

63) Haznedaroglu IC, Ozturk MA: Towards the understanding of the local hematopoietic bone marrow renin-angiotensin system. Int J Biochem Cell Biol. 2003; 35: 867-880.

64) Sata M, Tanaka K, Nagai R: Origin of smooth muscle progenitor cells: Different conclusions from different models. Circulation. 2003; 107: e106-e107.

65) Sata M, Tanaka K, Nagai R: Circulating osteoblast-lineage cells. N Engl J Med. 2005; 353: 737-738.

66) Sata M: Molecular strategies to treat vascular diseases. Circ J. 2003; 67: 983-991.

67) Sata M: Role of circulating vascular progenitors in angiogenesis, vascular healing, and pulmonary hypertension: Lessons from animal models. Arterioscler Thromb Vasc Biol. 2006; 26: 1008-1014.

68) Sata M: Circulating vascular progenitor cells contribute to vascular repair, remodeling, and lesion formation. Trends Cardiovasc Med. 2003; 13: 249-253.

69) Fukuda D, Shimada K, Tanaka A, Kawarabayashi T, Yoshiyama M, Yoshikawa J: Circulating monocytes and in-stent neointima after coronary stent implantation. J Am Coll Cardiol. 2004; 43: 18-23.

70) Fukuda D, Sata M, Tanaka K, Nagai R: Potent inhibitory effect of sirolimus on circulating vascular progenitor cells. Circulation. 2005; 111: 926-931.

71) Inoue $T$, Sata M, Hikichi Y, Sohma R, Fukuda D, Uchida T, Shimizu M, Komoda H, Node K: Mobilization of CD34-positive bone marrow-derived cells after coronary stent implantation: Impact on restenosis. Circulation. 2007; 115: 553-561.

72) Caplice NM, Bunch TJ, Stalboerger PG, Wang S, Simper D, Miller DV, Russell SJ, Litzow MR, Edwards WD: Smooth muscle cells in human coronary atherosclerosis can originate from cells administered at marrow transplantation. Proc Natl Acad Sci U S A. 2003 ; 100: 4754-4759.

73) Quaini F, Urbanek K, Beltrami AP, Finato N, Beltrami CA, Nadal-Ginard B, Kajstura J, Leri A, Anversa P.: Chimerism of the transplanted heart. $\mathrm{N}$ Engl J Med. 2002; 346: 5-15.

74) Schwartz SM: Perspectives series: Cell adhesion in vascular biology. Smooth muscle migration in atherosclerosis and restenosis. J Clin Invest. 1997; 99: 2814-2816.

75) Ross R: Atherosclerosis--an inflammatory disease. N Engl J Med. 1999; 340: 115-126.

76) Bauters C, Isner JM: The biology of restenosis. Prog Cardiovasc Dis. 1997; 40: 107-116.

77) Libby P, Schwartz D, Brogi E, Tanaka H, Clinton SK: A cascade model for restenosis. A special case of atherosclerosis progression. Circulation. 1992; 86: III47-III52.

78) Carmeliet P, Moons L, Stassen JM, De Mol M, Bouche A, van den Oord JJ, Kockx M, Collen D: Vascular wound healing and neointima formation induced by perivascular electric injury in mice. Am 
J Pathol. 1997; 150: 761-776.

79) Asahara T, Masuda H, Takahashi T, Kalka C, Pastore C, Silver M, Kearne M, Magner M, Isner JM: Bone marrow origin of endothelial progenitor cells responsible for postnatal vasculogenesis in physiological and pathological neovascularization. Circ Res. 1999; 85: 221-228.

80) Shintani S, Murohara T, Ikeda H, Ueno T, Honma T, Katoh A, Sasaki K, Shimada T, Oike Y, Imaizumi $\mathrm{T}$ : Mobilization of endothelial progenitor cells in patients with acute myocardial infarction. Circulation. 2001; 103: 2776-2779.

81) Imanishi T, Hano T, Nishio I: Angiotensin II potentiates vascular endothelial growth factor-induced proliferation and network formation of endothelial progenitor cells. Hypertens Res. 2004; 27: 101-108.

82) Ito $\mathrm{K}$, Hirao A, Arai F, Takubo K, Matsuoka S, Miyamoto K, Ohmura M, Naka K, Hosokawa K, Ikeda Y, Suda T: Reactive oxygen species act through p38 MAPK to limit the lifespan of hematopoietic stem cells. Nat Med. 2006; 12: 446-451.

83) Sasaki K, Murohara T, Ikeda H, Sugaya T, Shimada $\mathrm{T}$, Shintani S, Imaizumi T: Evidence for the importance of angiotensin II type 1 receptor in ischemia-induced angiogenesis. J Clin Invest. 2002; 109: 603-611.

84) Bahlmann FH, de Groot K, Mueller O, Hertel B, Haller H, Fliser D: Stimulation of endothelial progenitor cells: A new putative therapeutic effect of angiotensin II receptor antagonists. Hypertension. 2005; 45: 526-529.

85) Sata M, Nagai R: Inflammation, angiogenesis, and endothelial progenitor cells: How do endothelial progenitor cells find their place? J Mol Cell Cardiol. 2004; 36: 459-463.

86) Phillips MI, Kagiyama S: Angiotensin II as a pro-inflammatory mediator. Curr Opin Investig Drugs. 2002; 3: 569-577. 